\title{
Aromaterapi Lemon Dan Wedang Jahe Dapat Menurunkan Mual Muntah Pada Ibu Hamil Di Kota Medan
}

\author{
Yulina Dwi Hastuty \\ Jurusan Kebidanan Poltekkes Kemenkes Medan \\ e-mail: yulinadwihastuty@gmail.com
}

\begin{abstract}
Various complaints that interfere with pregnancy during pregnancy, one of which is nausea and vomiting in early pregnancy. Nausea and vomiting are common symptoms in pregnancy, almost 70-85\% of pregnant women experience nausea and vomiting in the first trimester. This can cause tissue damage that can endanger the health of the mother and the development of the fetus. Interventions for the management of nausea and vomiting in pregnancy can be carried out pharmacologically and non-pharmacologically. Pharmacological methods have unfavorable side effects, while non-pharmacological methods are cheap, simple, effective, and safer. This study aims to determine the effect of offering lemon aromatherapy and ginger on reducing nausea and vomiting in pregnant women in Medan. This research with pre test post test group design. The sample was pregnant women who came to the clinic with complaints of nausea and vomiting which was determined by 79 people who were determined to be 2 treatment groups. Sampling using simple random sampling technique according to the inclusion criteria. Data analysis used Wilcoxon test with $\alpha=0.05$. The results showed that offering ginger and lemon aromatherapy can reduce nausea and vomiting scores in pregnant women with a significance level of $p=0.001$ respectively. The conclusion is lemon aromatherapy and ginger reduce nausea and vomiting.
\end{abstract}

Key words: Ginger, pregnancy, lemon, non pharmacology, first trimester.

\begin{abstract}
ABSTRAK
Berbagai keluhan dapat terjadi pada masa kehamilan, satu diantaranya adalah mual dan muntah pada awal kehamilan. Mual dan muntah adalah gejala yang wajar dan sering didapatkan pada kehamilan, hampir 70$85 \%$ wanita hamil mengalami mual muntah pada trimester pertama. Hal ini dapat menimbulkan kerusakan jaringan yang dapat membahayakan kesehatan ibu dan perkembangan janin yang dikandungnya. Intervensi untuk penanganan mual muntah pada kehamilan dapat dilakukan secara farmakologi dan non farmakologi. Metode farmakologi berpotensi mempunyai efek samping yang kurang baik, sedangkan metode nonfarmakologi bersifat murah, simpel, efektif, dan lebih aman. Penelitian ini bertujuan untuk melihat pengaruh pemberian aromaterapi lemon dan wedang jahe terhadap penurunan mual muntah pada ibu hamil yang ada di kota Medan. Penelitian pre Eksperimental dengan desain pre test post test group design. Sampel penelitian adalah ibu hamil yang datang ke klinik dengan keluhan mual muntah yang berjumlah 79 orang yang ditentukan menjadi 2 kelompok perlakuan. Pengambilan sampel dengan teknik simple random sampling sesuai kriteria inklusi. Analisis data menggunakan uji wilcoxon dengan $\alpha=0,05$. Hasil penelitian menunjukkan bahwa pemberian wedang jahe dan aromaterapi lemon dapat menurunkan skor mual muntah pada ibu hamil dengan tingkat signifikansi masing-masing $\mathrm{p}=0.001$, Kesimpulan yang didapat bahwa aromaterapi lemon dan wedang jahe berperan menurunkan mual muntah.
\end{abstract}

Kata kunci: Jahe, kehamilan, lemon, non farmakologi, trimester pertama 


\section{PENDAHULUAN}

Kehamilan merupakan suatu proses reproduksi yang memerlukan perawatan khusus agar dapat berlangsung dengan baik demi tercapainya persalinan yang aman dan melahirkan bayi yang sehat dengan harapan dapat menekan Angka Kematian Ibu (AKI) dan Angka Kematian Bayi (AKB). Kehamilan merupakan kondisi krisis yang memerlukan adaptasi psikologis dan fisiologis terhadap hormon kehamilan dan tekanan mekanis akibat pembesaran uterus dan jaringan lain (Rofi'ah, S., 2017). Kehamilan juga dapat menyebabkan terjadinya perubahan fisik, psikis dan hormonal pada tubuh ibu. Hal tersebut menimbulkan bermacam-macam keluhan, salah satunya adalah mual muntah atau morning sickness yang biasa terjadi pada awal kehamilan (Husin F, 2014).

Mual muntah merupakan salah satu gejala paling awal, paling umum dan paling menyebabkan stress yang dikaitkan dengan kehamilan (Tiran, 2013). Hampir 70-85\% perempuan hamil mengalami mual muntah pada trimester pertama kehamilan (5-12 minggu) (Jarvis, S. dan Nelson-Piercy, 2011). Mual dan muntah terjadi pada $60-80 \%$ primigravida dan 40-60\% multigravida (Prawirohardjo, 2014). Mual dan muntah seringkali diabaikan karena dianggap sebagai sebuah konsekuensi diawal kehamilan (Aritonang, 2010)

Mual dan muntah pada kehamilan biasanya bersifat ringan dan merupakan kondisi yang dapat dikontrol sesuai dengan kondisi ibu hamil. Data WHO (World Health Organization, 2013) jumlah kejadian mual dan muntah mencapai $12,5 \%$ dari jumlah kehamilan di dunia. Di Indonesia terdapat 50-90\% kasus mual dan muntah yang dialami oleh ibu hamil. Prevalensi mual muntah di Indonesia juga berbeda-beda disetiap daerah. Elsa dkk, menemukan ibu hamil trimester 1 yang mual muntah di Boyolali sebesar 42,86\% (Elsa W, 2012). Selanjutnya, Rinata dan Ardilla (2017) mengemukakan sebanyak $60 \%$ ibu hamil mengalami mual muntah di Sidoarjo. Mariantari 2014, juga melaporkan bahwa sebanyak 27 orang
(71,1\%) ibu hamil di Pekanbaru mengalami mual muntah (Mariantari, Y. dan Lestari 2014,) .

Mual muntah dalam keadaan normal tidak banyak menimbulkan efek negatif dan biasanya berhenti pada trimester pertama, hanya saja apabila mual muntah berkelanjutan dapat menjadi hiperemesis gravidarum dan akan membawa resiko pada ibu dan janin yang dikandungnya karena dapat menyebabkan terjadinya gangguan pada kehamilan seperti cadangan karbohidrat dalam tubuh ibu akan habis, dehidrasi, gangguan keseimbangan elektrolit, acidosis, syok, robekan pada selaput jaringan esophagus dan lambung dapat terjadi bila muntah terlalu sering dan memiliki resiko yang lebih tinggi untuk terjadi tumbuh kembang janin terhambat, bayi dengan berat badan lahir rendah, prematur, dan nilai apgar kurang dari tujuh (Manuaba, 2014). Mengatasi mual muntah selama masa kehamilan dapat dilakukan melalui tindakan farmakologi maupun non farmakologi. Tindakan non farmakologi atau terapi komplementer yang biasa disarankan oleh tenaga kesehatan seperti menganjurkan ibu hamil untuk mengkonsumsi jahe dalam bentuk teh jahe, teknik relaksasi seperti akupresur dan aromaterapi (Rahmawati, 2010; McParlin, C, 2016).

Beberapa hasil penelitian menunjukkan bahwa jahe merupakan bahan terapi untuk meredakan dan mengurangi rasa mual dan muntah (Wiraharja, R.S., dkk, 2011). Selain itu jahe juga efektif dalam mengurangi mual muntah pada ibu hamil trimester pertama kehamilan dan menurunkan mual muntah pada ibu yang multigravida (Saswita, Dewi, 2011) Hasil penelitian (Gunanegara, 2009) menyatakan bahwa kombinasi ekstrak jahe dengan piridoksin dapat meringankan gejala mual muntah lebih baik daripada hanya menggunakan piridoksin saja.

Jahe merupakan tanaman obat dan juga rempah-rempah yang sudah lama dikenal oleh masyarakat Indonesia. Jahe hampir tersebar diseluruh daerah tropika basah di Kawasan Asia. Sentrum utama tanaman jahe di Indonesia adalah 
Vol. 16 No. 2 Mei - Agustus 2021

Sumatera Utara, Bengkulu, Jawa Barat, Jawa Tengah, dan Jawa Timur (Setyaningrum, 2013). Jahe dapat mengendurkan dan melemahkan otototot saluran pencernaan sehingga mual dan muntah dapat berkurang (Parwitasari, C.D. dan Utami, 2014). Penelitian yang dilakukan Putri 2017 mendapati sebelum diberi intervensi ratarata responden mengalami frekuensi mual muntah sebanyak 13 kali dalam sehari, setelah diberi intervensi minuman jahe hangat rata-rata frekuensi mual muntah menurun menjadi 3,18 kali dalam sehari. (Putri, A.D., 2017) Penelitian dari Hasanah 2014, menunjukkan bahwa ada perbedaan yang signifikan penurunan frekuensi mual muntah setelah diberikan wedang jahe (Hasanah, 2014) .

Metode lain yang dapat digunakan untuk mengurangi mual muntah pada ibu hamil adalah dengan aromaterapi. Aromaterapi adalah minyak tumbuhan yang harum dan mempunyai konsentrasi tinggi dan mudah mengalami penguapan (Potts, 2009). Prinsip utama aromaterapi yaitu pemanfaatan bau dari tumbuhan atau bunga untuk mengubah kondisi perasaan, psikologi, status spiritual dan mempengaruhi kondisi fisik seseorang. Sumber minyak yang digunakan sebagai aromaterapi diantaranya berasal dari peppermint, bunga lavender, bunga mawar, jahe, lemon. Prinsip kerja aromaterapi di dalam tubuh yaitu memacu pelepasan neurotransmitter seperti ensepalin dan endorphin yang mempunyai efek analgesic dan meningkatkan perasaan nyaman dan rileks (Potts, 2009), efek aromaterapi lemon yang menenangkan juga dapat menghilangkan kecemasan pada pasien yang dioperasi (Kamrani,F, 2016). Lemon minyak esensial adalah salah satu yang paling banyak digunakan minyak herbal dalam kehamilan dan dianggap obat yang aman pada kehamilan. Menurut sebuah studi, $40 \%$ wanita telah menggunakan aroma lemon untuk meredakan mual muntah dan $26,5 \%$ dari mereka telah melaporkan aromaterapi lemon sebagai cara yang efektif untuk mengontrol gejala mual muntah (Kia et al, 2014). Berdasarkan hasil penelitian yang dilakukan oleh (Astriana, dkk, 2015), didapatkan hasil bahwa pemberian lemon inhalasi aromaterapi berpengaruh terhadap mual pada ibu hamil. Hal ini juga sejalan dengan hasil penelitian yang dilakukan (Materniti, D.,dkk, 2016) yang mendapati adanya pengaruh inhalasi aromaterapi lemon terhadap Morning Sickness pada ibu hamil.

Jumlah kunjungan ibu yang melakuan pemeriksaan kehamilan di satu klinik yang ada di kota Medan rata-rata 40 orang perbulan dan yang mengalami mual muntah rata-rata 20 orang perbulan. Penatalaksanaan yang dilakukan untuk mengatasi keluhan yang dialami oleh ibu hamil juga masih belum mampu meredakan mual muntah secara maksimal mengingat efek samping yang bisa terjadi jika diberikan terapi secara farmakologi.

Saat ini penggunaan terapi non farmakologi yang berupa terapi komplementer menjadi pilihan yang cukup aman bagi ibu hamil yang mengalami mual muntah, namun dari berbagai jenis terapi tersebut belum pernah diteliti mana yang lebih cepat dan efektif dalam menurunkan mual muntah pada ibu hamil. Berdasarkan hal tersebut peneliti tertarik untuk melakukan penelitian untuk melihat efektifitas pemberian terapi komplementer dalam hal ini pemberian teh jahe dan aromaterapi lemon terhadap penurunan mual muntah pada ibu hamil di kota Medan.

\section{METODE; JENIS PENELITIAN}

Jenis Penelitian yang digunakan adalah pre Eksperimental dengan desain pre test post test group design.

LOKASI DAN WAKTU PENELITIAN 
Penelitian ini dilakukan di kota Medan. Penelitian ini dilaksanakan pada bulan Juli September 2019

\section{POPULASI DAN SAMPEL}

Populasi dalam penelitian ini adalah ibu hamil yang datang ke beberapa klinik yang ada di kota Medan, dengan keluhan mual muntah Sampel berjumlah 79 orang dibagi menjadi 2 kelompok perlakuan. Pengambilan sampel dengan teknik simple random sampling sesuai kriteria inklusi,

\section{PENGUMPULAN DATA}

Data dikumpulkan secara langsung dari ibu hamil yang mengalami mual muntah. Pengukuran mual muntah dengan kuesioner PUQE (Ebrahimi, N.,et al, 2009).

\section{PENGOLAHAN DAN ANALISIS DATA}

Data yang sudah terkumpul diolah dan dianalisis menggunakan program komputer. Analisis data menggunakan uji wilcoxon $\alpha=$ 0,05 .

\section{HASIL PENELITIAN}

1. Pengaruh Pemberian Wedang Jahe pada Ibu Hamil dengan Mual Dan Muntah di Klinik Bersalin yang ada di Kota Medan.

Pengaruh pemberian wedang jahe pada ibu hamil dengan mual muntah dapat dilihat pada tabel dibawah ini:

Tabel 1. Pengaruh Pemberian Wedang Jahe pada Ibu Hamil di Klinik Bersalin yang ada di Kota Medan

\begin{tabular}{lccccc}
\hline Variabel & $\begin{array}{c}\text { Pre test-post } \\
\text { test }\end{array}$ & $\begin{array}{c}\text { Mean } \\
\text { Rank }\end{array}$ & $\begin{array}{c}\text { Jlh } \\
\text { Rank }\end{array}$ & $\begin{array}{c}\text { P } \\
\text { value }\end{array}$ \\
\hline Wedang & $\begin{array}{c}\text { Negative } \\
\text { Jahe }\end{array}$ & 39 & 20 & 780 & 0,001 \\
& Rank & & & & \\
& $\begin{array}{c}\text { Positive } \\
\text { Rank }\end{array}$ & 0 & & & \\
& Ties & 0 & & & \\
& & & & \\
\hline
\end{tabular}

Selisih negative skor mual muntah dengan pemberian wedang jahe pada penilaian pre test dan post test adalah 39, artinya terdapat 39 responden yang terjadi penurunan mual muntah setelah diberikan wedang jahe dari penilaian pre test ke post test, dan rata-rata penurunan tersebut adalah 20, sedangkan jumlah rank negative adalah 780. Tidak ditemukan nilai yang sama dari pre test dan post test (Ties $=0$ ). Hasil uji statistik didapatkan nilai $P=0,001$ maka dapat disimpulkan ada pengaruh yang signifikan antara skor mual muntah pada ibu hamil sebelum perlakuan dan sesudah dilakukan perlakuan

\section{Pengaruh pemberian tindakan} aromaterapi lemon pada ibu hamil dengan mual dan muntah di Klinik Bersalin yang ada di Kota Medan

Pengaruh pemberian tindakan aromaterapi lemon pada ibu hamil dengan mual muntah dapat dilihat pada tabel dibawah ini:

Tabel 2. Pengaruh Pemberian aromaterapi lemon pada Ibu Hamil di Klinik Bersalin

\begin{tabular}{|c|c|c|c|c|c|c|}
\hline \multirow{2}{*}{$\begin{array}{l}\text { Variabel } \\
\text { Aromate } \\
\text { rapi } \\
\text { Lemon }\end{array}$} & \multicolumn{2}{|c|}{$\begin{array}{c}\text { Pre test-post } \\
\text { test }\end{array}$} & \multirow{2}{*}{$\begin{array}{l}\text { Mean } \\
\text { Rank } \\
20.50\end{array}$} & \multirow{2}{*}{$\begin{array}{c}\begin{array}{c}\text { Jlh } \\
\text { Rank }\end{array} \\
820\end{array}$} & \multirow{2}{*}{$\begin{array}{c}\mathrm{P} \\
\text { value } \\
0,001\end{array}$} & \multirow{2}{*}{$\begin{array}{l}\mathrm{n} \\
40\end{array}$} \\
\hline & $\begin{array}{c}\text { Negative } \\
\text { Rank }\end{array}$ & 40 & & & & \\
\hline & $\begin{array}{c}\text { Positive } \\
\text { Rank } \\
\text { Ties }\end{array}$ & 0 & & & & \\
\hline
\end{tabular}

Selisih negative skor mual muntah dengan pemberian aromaterapi lemon pada penilaian pre test dan post test adalah 40 , artinya terdapat 40 responden yang terjadi penurunan nhual muntah setelah diberikan aromaterapi lemon dari penilaian pre test ke post test, dan rata-rata penurunan tersebut adalah 20.50, sedangkan jumlah rank negative adalah 820 . Tidak ditemukan nilai yang sama dari pre test dan post test (Ties $=0)$. Hasil uji statistik didapatkan nilai $P=0,001$ maka dapat disimpulkan ada 
Vol. 16 No.2 Mei - Agustus 2021

pengaruh yang signifikan antara skor mual muntah pada ibu hamil sebelum perlakuan dan sesudah dilakukan perlakuan

\section{PEMBAHASAN}

\section{Pengaruh Pemberian Wedang Jahe pada Ibu Hamil dengan Mual Dan Muntah di Klinik Bersalin yang ada di Kota Medan.}

Hasil penelitian menyebutkan bahwa sebelum diberi intervensi rata-rata responden mengalami frekuensi mual muntah sebanyak 13 kali dalam sehari, setelah diberi intervensi minuman jahe hangat rata-rata frekuensi mual muntah menurun menjadi 3,18 kali dalam sehari dengan nilai $\mathrm{p}=0,000$. Hasil penelitian ini dapat disimpulkan bahwa baik secara klinis maupun statistik, minuman jahe hangat memberikan pengaruh terhadap penurunan frekuensi mual muntah pada ibu hamil trimester pertama.

Jahe dapat mencegah mual dan muntah karena jahe mampu menjadi penghalang serotinin, sebuah senyawa kimia yang dapat menyebabkan perut berkontraksi, sehingga timbul rasa mual. Penelitian lain menunjukkan hasil bahwa jahe efektif dalam mengurangi mual dan muntah selama kehamilan trimester I, yang dibuktikan dengan hasil uji hipotesis adanya penurunan rata-rata penurunan mual dan muntah sebelum diberikan intervensi sebesar 3,87 dan setelah diberikan intervensi 2,78 p-value 0,014 $(<\alpha=0,05)$ (Saswita, Dewi, 2011). Selain itu penelitian lain memaparkan bahwa rasa mual pada awal kehamilan dapat di kurangi dengan menggunakan terapi komplementer antara lain dengan tanaman herbal atau tradisional yang bisa dilakukan dan mudah di dapatkan seperti jahe, daun peppermint, lemon, dll (Ira, 2012). Hasil penelitian ini sesuai dengan penelitian lain yang menyatakan bahwa jahe bekerja efektif untuk mengatasi gejala mual dan muntah yang timbul selama masa kehamilan bahkan hiperemesis gravidarum, karena jahe berkhasiat mengendurkan dan melemahkan otot-otot pada saluran pencernaan sehingga mengurangi mual muntah pada ibu hamil.

Hasil penelitian ini juga sejalan dengan penelitian yang memaparkan bahwa pemberian terapi minuman jahe menunjukan penurunan morning sickness pada ibu hamil trimester I, sesudah diberikan terapi minuman jahe (Alyamaniyah, U.H. dan Mahmudah, 2014). Penelitian lain yang membandingkan antara rebusan jahe dengan daun mint, diperoleh hasil bahwa pada kelompok jahe diperoleh selisih 9,87 sedangkan daun mint 6,66, sehingga dapat disimpulkan bahwa pemberian rebusan jahe lebih efektif dibanding daun mint (Parwitasari, C.D. dan Utami, 2014). Hasil penelitian lain tentang perbandingan efektivitas wedang jahe dengan piridoksin dalam mengurangi mual muntah pada wanita hamil. Menunjukkan bahwa wedang jahe lebih baik untuk mengurangi keluhan mual muntah pada ibu hamil dibandingkan piridoksin (Sumiaty, 2018). Beberapa peneliti menganjurkan dosis ekstrak jahe yang aman untuk konsumsi ibu hamil di bawah 1000 $\mathrm{mg} /$ hari, sama seperti dosis yang kita dapat dari makanan sehari-hari, beberapa peneliti juga menemukan bahwa ekstrak jahe ternyata lebih efektif bila dikombinasikan dengan Piridoksin.

Kandungan di dalam jahe terdapat minyak Atsiri Zingiberena (zingirona), zingiberol, bisabilena, kurkumen, gingerol, flandrena, vit A dan resin pahit yang dapat memblok serotinin yaitu suatu neurotransmitter yang di sintesiskan pada neuron-neuron serotonergis dalam sistem saraf pusat dan sel-se lenterokromafin dalam saluran pencernaan sehingga di percaya dapat sebagai pemberi perasaan nyaman dalam perut sehingga dipercaya sebagai pemberi perasaan nyaman dalam perut sehingga dapat mengatasi mual muntah (Ahmad, 2013). 
Hasil penelitian ini sejalan dengan penelitian yang dilakukan oleh (Saswita, Dewi, 2011) yang menyatakan bahwa penurunan ratarata mual dan muntah sebelum diberikan intervensi sebesar 3,87 dan setelah diberikan intervensi 2,78 dengan $p$ value 0,014. Dapat disimpulkan bahwa jahe efektif dalam mengurangi mual dan muntah selama kehamilan trimester pertama. Riset yang dilakukan membuktikan keefektifan khasiat jahe pada ibu hamil dalam mengatasi mual muntah. Pemberian suplemen yang mengandung 1 gram ekstrak jahe setiap hari, memperlihatkan hasil yang memuaskan dimana terjadi penurunan gejala mual muntah yang signifikan pada ibu hamil (Hasanah, 2014).

Jahe berkhasiat sebagai anti muntah dan dapat digunakan bagi ibu hamil untuk mengurangi morning sickness. Penelitian menunjukkan bahwa jahe sangat efektif menurunkan metoklopamid senyawa penginduksi mual dan muntah. Jahe putih kecil memiliki kandungan minyak atsirinya lebih besar dari pada jahe gajah, sehingga rasanya lebih pedas, disamping seratnya tinggi dan sering ditemukan dipasaran, sehingga jahe dapat dijadikan sebagai pengobatan alternatif untuk mengatasi emesis gravidarum sebelum menggunakan obat antiemetik. Kandungan wedang jahe aman dari bahan berbahaya karena dapat dibuat sendiri sehingga ibu hamil tidak perlu khawatir akan membahayakan kehamilan dan janinnya (Putri, A.D., 2017). Mekanisme jahe memiliki efek langsung dalam saluran pencernaan dengan meningkatkan pergerakan lambung, serta absorbsi racun dan asam. Jahe dipercaya sebagai pemberi perasaan nyaman dalam perut sehingga dapat mengatasi mual muntah karena kandungan minyak Atsiri Zingiberena, Zingiberol, Bisabilena, Kurkuman, Gingerol, Flandrena, vit A dan resin pahit. Kandungan zat-zat tersebut memblok serotonin dan menghambat induksi HCG ke lambung. Hasil penelitian menyebutkan bahwa ada efek menguntungkan dari minum jahe bagi wanita karena jahe dapat mengurangi rasa mual dan muntah, bahwa jahe berkhasiat mengendurkan dan melemahkan otot-otot pada saluran pencernaan sehingga mual muntah banyak berkurang.

\section{Pengaruh pemberian tindakan aromatherapy lemon pada ibu hamil dengan mual dan muntah di Klinik Bersalin yang ada di Kota Medan.}

Berdasarkan hasil penelitian didapatkan bahwa selisih rata-rata frekuensi mual muntah sebelum diberikan inhalasi aromaterapi lemon dan setelah diberikan inhalasi aromaterapi lemon pada ibu hamil dengan emesis gravidarum adalah 7,8 dan nilai $\mathrm{p}=0,000$ artinya terdapat perbedaan rata-rata frekuensi mual dan muntah ibu hamil emesis gravidarum yang signifikan antara sebelum dan setelah diberikan inhalasi aromaterapi lemon.

Emesis gravidarum bila tidak ditangani dengan tepat dapat menjadi Hiperemesis gravidarum dimana kondisi ini merupakan komplikasi mual dan muntah pada hamil muda dan bila terjadi terus-menerus dapat menyebabkan dehidrasi dan tidak imbangnya elektrolit dengan alkosis hipokloremik (Rahmawati, 2010). Selain itu hiperemesis gravidarum juga dapat mengakibatkan cadangan karbohidrat dan lemak habis terpakai untuk keperluan energi karena oksidasi lemak yang tidak sempurna tejadilah ketosis dengan tertimbunnya asam aseton-asetik, asam hidroksi butirik dan aseton dalam darah. Untuk mencegah agar hiperemesis gravidarum tidak menyebabkan komplikasi lebih lanjut maka diperlukan penanganan yang tepat dan efisien.

Penanganan emesis gravidarum secara umum yaitu secara farmakologis dan non farmakologis. Penanganan secara farmakologis dengan pemberian obat-obatan anti mual. Penanganan secara farmakologis di anggap mahal oleh masyarakat, selain itu penanganan farmakologis juga mempunyai efek samping. Efek samping tersebut bermacam-macam tergantung dari obat yang digunakan. Salah satu 
Vol. 16 No.2 Mei - Agustus 2021

penanganan non farmakologis dalam menyembuhkan mual muntah pada ibu hamil adalah terapi komplementer. Terapi komplementer bersifat terapi pengobatan alamiah diantaranya adalah pemberian aromaterapi lemon.

Dalam penelitian ini untuk melihat perbedaan frekuensi mual muntah sebelum dan setelah diberikan inhalasi aromaterapi lemon dilakukan analisis dengan menggunakan wilcoxon. Dari hasil penelitian diketahui bahwa terdapat perbedaan frekuensi mual muntah pada ibu hamil sebelum dan setelah diberikan inhalasi aromaterapi lemon dengan p-value $=0.001$.

Penelitian ini sejalan dengan penelitian yang dilakukan (Saridewi W, 2018) tentang pemberian lemon aromaterapi mampu menurunkan mual muntah pada kehamilan. Sama hal nya dengan penelitian yang dilakukan (Materniti, D., dkk, 2016) yang mengemukakan bahwa terdapat penurunan mual muntah pada kehamilan yang signifikan yaitu dengan nilai $\mathrm{p}$ value $0.0001 \quad(\mathrm{p}<0.05)$ setelah menggunakan inhalasi aromaterapi lemon.

Frekuensi mual muntah pada ibu hamil diakibatkan oleh faktor psikologik yang memegang peranan penting pada penyakit ini. Pekerjaan, jumlah kehamilan, takut terhadap kehamilan dan persalinan karena kurangnya pemahaman, takut terhadap tanggung jawab sebagai ibu karena berbagai faktor termasuk usia dini, dapat menyebabkan konflik mental yang dapat memperberat mual dan muntah sebagai ekspresi tidak sadar terhadap keengganan menjadi hamil. Dari penelitian yang telah dilakukan kepada ibu hamil yang mengalami mual muntah didapatkan inhalasi aromaterapi lemon dapat meminimalisir terjadinya mual muntah yang berlebihan pada ibu hamil jika responden teratur dalam memakai inhalasi aromaterapi lemon tersebut. Lemon juga memiliki kandungan yang dapat menurunkan mual muntah pada ibu hamil.
Kerja aromaterapi dalam menurunkan mual muntah adalah memacu pelepasan neurotransmitter seperti ansepalin dan endorphin yang mempunyai efek analgesic dan meningkatkan perasaan nyaman dan rileks (Potts, 2009). Dalam penelitian ini menunjukkan bahwa inhalasi aromaterapi lemon dapat mengurangi frekuensi mual muntah pada ibu hamil. Namun dalam pemanfaatan tanamantanaman alami ini responden harus memiliki kemauan dan kesabaran yang besar untuk melakukannya, karena hasil dari pemanfaatan atau penggunaan tanaman- tanaman alami tidak langsung memberikan pengaruh yang nyata pada mual muntah, namun butuh waktu dan cara yang benar dalam pemanfaatannya.

\section{KESIMPULAN}

Secara umum rerata skor mual muntah pada ibu hamil mengalami penurunan setelah diberikan perlakuan pemberian aromaterapi lemon dan wedang jahe.Pemberian aromaterapi lemon dan pemberian wedang jahe berpengaruh terhadap penurunan mual muntah pada ibu hamil dengan nilai signifikansi masing-masing kelompok perlakuan $\mathrm{p}=0.001$.

\section{SARAN}

Perlu dilakukan penelitian lebih lanjut terkait pemanfaatan terapi herbal lain dalam mengatasi permasalahan kesehatan dan menganjurkan pada pihak terkait seperti klinik dan pelayanan kesehatan lainnya untuk menggunakan terapi alternatif (komplementer) yang aman dalam mengatasi mual muntah pada ibu hamil.

\section{DAFTAR PUSTAKA}

Ahmad, J. (2013) Aneka manfaat ampuh rimpang jahe untuk pengobatan. 
Yogyakarta: Dandra pustaka indonesia.

Alyamaniyah, U.H. dan Mahmudah, M. (2014)

'Efektivitas Pemberian Wedang Jahe (Zingiber Officinale Var. Rubrum) Terhadap Penurunan Emesis Gravidarum Pada Trimester Pertama', Jurnal Biometrika dan Kependudukan, p8187(3(1)).

Aritonang, E. (2010) Kebutuhan Gizi Ibu Hamil. Bogor: IPB Press.

Astriana, A., dkk. (2015) 'Pengaruh Lemon Inhalasi Aromatherapy Terhadap Mual Pada Kehamilan di BPS Varia Mega Lestari S. ST., M. Kes Batupuru Kecamatan Natar Kabupaten Lampung Selatan Tahun 2015', Jurnal Kebidanan Malahayati, (1(3).).

Ebrahimi, N., et al. (2009) 'Nausea and vomiting of pregnancy: using the 24-hour Pregnancy-Unique Quantification of Emesis (PUQE-24) scale.', Journal of Obstetrics and Gynaecology Canada, pp.803-807(31(9),).

Elsa W, dkk (2012) 'Hubungan Paritas Ibu Hamil Trimester I Dengan Kejadian Emesis Gravidarum Di Puskesmas Teras', Jurnal Kebidanan, 4(2), pp. 35-48.

Gunanegara (2009) 'Perbandingan Efektivitas Kombinasi Ekstrak Jahe dan Piridoksin dengan Piridoksin Saja dalam Mengurangi Keluhan Mual Muntah pada Wanita Hamil', JKM, 9(1), pp. 24-33.

Hasanah (2014) 'Efektivitas Pemberian Wedang Jahe (Zingiber Officinale Var. Rubrum) terhadap Penurunan Emesis Gravidarum pada Trimester Pertama', Jurnal Biometrika dan Kependudukan, 3(1), pp. 81-87.

Husin F (2014) Asuhan Kehamilan Berbasis Bukti, Jakarta CV Sagung Seto.

Ira, P. (2012) Pengobatan mandiri di rumah anda a-z gangguan kesehatan umum, cara mencegah dan cara mengatasinya. Yogyakarta: Bangkit.

Jarvis, S. dan Nelson-Piercy, C. (2011) 'Management of nausea and vomiting in pregnancy', Bmj.

Kamrani,F, et al (2016) 'Aromatherapy with lemon Essential Oil on Anxiety after Orthopedic Surgery. Iranian', Journal of Rehabilitation Research in Nursing.IJRN, 2(4), pp. 26-31.

Kia et al (2014) 'The effect of lemon inhalation aromatherapy on nausea and vomiting of pregnancy: a double-blinded, randomized, controlled clinical trial. Iranian', Red Crescent Medical Journal, 16(3).

Manuaba (2014) 'Penyakit Kandungan dan KB Untuk Pendidikan', Bidan, in Ilmu Kebidanan. doi: doi: 10.1039/B9PY00221A.

Mariantari, Y. dan Lestari, W (2014). 'Hubungan Dukungan Suami, Usia Ibu, dan Gravida terhadap Kejadian Emesis Gravidarum', Jurnal Online Mahasiswa Program Studi Ilmu Keperawatan Universitas Riau, 1(2), pp. 1-9.

Materniti,D.dkk. (2016) 'Pengaruh Inhalasi Aromaterapi Lemon Terhadap Morning Sickness Pada Ibu Hamil Di Wilayah Kerja Puskesmas Tulang Bawang I Kecamatan Banjar Agung Kabupaten Tulang Bawang Tahun 2016', Jurnal Kebidanan Malahayati, 2(3), pp. 115-120.

McParlin, C, et al (2016) 'Treatments for hyperemesis gravidarum and nausea and vomiting in pregnancy: a systematic review', Jama, 316(13), pp. 1392-1401.

Parwitasari, C.D. dan Utami, S. (2014) 'Perbandingan Efektivitas Pemberian Rebusan Jahe Dan Daun Mint Terhadap Mual Muntah Pada Ibu Hamil', Jurnal Online Mahasiswa Program Studi Ilmu Keperawatan Universitas Riau, 1(1), pp. 110.

Potts, J. (2009) 'Aromatherapy in Nursing Practice', Australian Nursing Journal.

Prawirohardjo, S. (2014) Ilmu kebidanan. Jakarta: Bina Pustaka.

Putri, A.D., dkk (2017) 'Efektifitas Pemberian Jahe Hangat Dalam Mengurangi Frekuensi Mual Muntah Pada Ibu Hamil 
Vol. 16 No.2 Mei - Agustus 2021

Trimester I. In Prosiding Seminar Nasional IKAKESMADA "Peran Tenaga Kesehatan dalam Pelaksanaan SDGs” (pp. 99-105). Fakultas Kesehatan Masyarakat Universitas Ahmad Dah'.

Rahmawati, N. (2010) Ilmu Praktis Kebidanan. Jakarta: Victory Inti Cipta.

Rofi'ah, S. (2017) 'Efektivitas Konsumsi Jahe dan Sereh dalam Mengatasi Morning Sickness', Jurnal Ilmiah Bidan, 1(1), pp. $57-63$.

Saridewi W, S. (2018) 'Pengaruh aromaterapi lemon terhadap emesis gravidarum di praktek mandiri bidan Wanti Mardiwati kota Cimahi', Jurnal Ilmiah Kesehatan dan Kebidanan, 17(3), pp. 4-8.

Saswita, Dewi, Y. I. and B. (2011) 'Efektifitas Minum Jahe dalam Mengurangi Emesis Gravidarum pada Ibu Hamil Trimester I', Jurnal Ners Indonesia, 1(2), pp. 1-10.

Setyaningrum, E. (2013) Asuhan Kegawatdaruratan Maternitas (Asuhan Kebidanan Patologi). In Media.

Sumiaty, E. dkk (2018) 'Efektivitas Vitamin B6 (Piridoksin) Dan Wedang Jahe Pada Ibu Hamil Dengan Emesis Gravidarum Di Polindes Terong Tawah Kecamatan Labuapi Kabupaten Lombok Barat', Prima Jurnal Ilmiah Ilmu Kesehatan STIKES Mataram, 4(2), pp. 105-112.

Tiran, D. (2013) Mual dan muntah Kehamilan. Jakarta: EGC.

Wiraharja, R.S., Heidy, H., Rustam, S. dan Iskandar, M. (2011) 'Kegunaan Jahe Untuk Mengatasi Gejala Mual Dalam Kehamilan.', Damianus Journal of Medicine, 10(3), pp. 161-170.

World Health Organization (2013) Buku Saku Pelayanan Kesehatan Ibu di Fasilitas Kesehatan Dasar dan Rujukan. Jakarta: Bina Kesehatan Ibu. 